\title{
A new black fly isolate of Bacillus thuringiensis autoagglutinating strain highly toxic to Simulium pertinax (Kollar) (Diptera, Simuliidae) larvae
}

\author{
Clara FG Cavados ${ }^{+}$, Rodrigo N Fonseca/ ${ }^{++}$, Jeane Q Chaves, \\ Carlos JPC Araújo-Coutinho*, Leon Rabinovitch
}

\author{
Departamento de Bacteriologia, Instituto Oswaldo Cruz-Fiocruz, Av. Brasil 4365, 21040-900 Rio de Janeiro, RJ, Brasil \\ *Superintendência de Controle de Endemias da Secretaria de Saúde do Estado de São Paulo, São Paulo, SP, Brasil
}

\begin{abstract}
Formulations containing the entomopathogenic Bacillus thuringiensis serovar israelensis strain IPS-82 has been widely applied for mosquito control around the world. Strain IPS-82 is highly active against Aedes aegypti but less active against other well-known vectors such as Culex quinquefasciatus and Simulium spp. larvae. Eighteen strains of B. thuringiensis were isolated from Simulium pertinax larvae naturally occurring in rivers of Southeast Brazil with one demonstrating special toxic effects. Simulated field tests against $\mathrm{S}$. pertinax larvae showed that the native Brazilian autoagglutinanting B. thuringiensis (LFB-FIOCRUZ 1035) has an LC $C_{50}$ at least 25 times lower than the standard IPS-82 strain. The same bacterial preparation was also tested against Ae. aegypti larvae in laboratory trials and the $L_{50}$ values obtained with LFB-FIOCRUZ 1035 were at least three times lower than the one for the IPS 82 strain. The results indicate that this strain is more toxic than the standard B. thuringiensis serovar israelensis (H14) in the two Dipteran species tested. It is noteworthy that differences between $L C_{50}$ values were more pronounced in $\mathrm{S}$. pertinax larvae, the source of the original isolation.
\end{abstract}

Key words: entomopathogenic bacteria - biological control - black fly

Bacillus thuringiensis is a Gram-positive, spore-forming bacterium which produces a parasporal body during sporulation. The proteins contained in the parasporal crystal (delta-endotoxins) are specific insect gut toxins which have no significant effect on non-target organisms (Siegel 2001). The mode of action after ingestion involves solubilization of the protein in the alkaline conditions of the insect midgut, followed by activation of the protoxin into toxin through cleavage of specific regions by gut proteases. Then, the so called toxin binds to specific receptors in the brush border membrane vesicles of the midgut columnar cells. The binding is a two-step process, the second part being the insertion of the toxin into the cell membrane leading to pore formation, osmotic imbalance, disruption of the cell membrane and finally, death of the insect (Van Rie et al. 1990, Knowles 1994).

The use of bioinsecticides based on $B$. thuringiensis to control insects from the orders Diptera, Coleoptera, and Lepidoptera and more recently against Hymenoptera, Orthoptera, and Mallophaga, has stimulated the search for other natural pathogens (Schenpf et al. 1998). Strains have been isolated from different sources, such as mud, silt, and soil. However, only a few reports have been published concerning the isolation of entomopathogenic $\mathrm{Ba}$ cillus from insects.

Financial partial support: Pibic Fellowship Program-Fiocruz ${ }^{+}$Corresponding author. Email: ccavados@ioc.fiocruz.br

${ }^{++}$Current address: Universität zu Köln, Institut für Entwicklungsbiologie D-50923 Köln Gyrhofstrasse 17

Received 4 May 2005

Accepted 25 October 2005
In 1984 , Weiser described a highly toxic strain of $B$. sphaericus isolated from an adult of Simulium damnosum in Northern Nigeria. This strain, known as B. sphaericus 2362 , is the one used in commercial bioinsecticides based on B. sphaericus. Asimeng and Mutinga (1992) and Chilcott and Wigley (1993) isolated several additional $B$. thuringiensis strains from Diptera larvae.

In Brazil, Rabinovitch et al. (1995), isolated two new $B$. thuringiensis serotypes from commercial peppers. These isolates belong to serotype $\mathrm{H}-38$ and H-39, B. thuringiensis serovar oswaldocruzi and B. thuringiensis serovar brasiliensis, respectively.

Between 1995 to 1998, an isolation program was set up to obtain entomopathogenic Bacillus from Simulium larvae and adults in the Southeast region of Brazil. Eighteen strains of B. thuringiensis and one of B. sphaericus were isolated (Cavados et al. 2001). Preliminary bioassays were performed and one of the B. thuringiensis strains (LFBFIOCRUZ 1035) showed promising activity against Aedes aegypti and Culex quinquefasciatus (Cavados et al. 2001).

In the present study, the toxicity of the autoagglutinating strain LFB-FIOCRUZ 1035 was evaluated against two Dipteran species, S. pertinax and Ae. aegypti larvae, and compared with a standard powder formulation of the reference $B$. thuringiensis serovar israelensis strain IPS82 , which is used in commercially available bioinsecticides.

\section{MATERIALS AND METHODS}

Bacterial strains - Two strains of B. thuringiensis were used, one of them IPS-82 (LFB-FIOCRUZ 584) serotype H-14, isolated from the standard powder prepared by the Pasteur Institute of Paris, and the other LFBFIOCRUZ 1035, an autoagglutinating strain isolated from S. pertinax larvae collected in a natural breeding-site in 
Southeastern Brazil (Cavados et al. 2001). Both are deposited as lyophilized material in the Coleção de Culturas do Gênero Bacillus e Correlatos - CCGB, of the Departamento de Bacteriologia, Instituto Oswaldo Cruz-IOCFiocruz.

Preparation of active bacterial biomass - The Brazilian strain LFB-FIOCRUZ 1035 and the standard IPS-82, were grown in a fermentation medium based on soy flour and inorganic salts (such as $\mathrm{MgSO}_{4}, \mathrm{MnSO}_{4}, \mathrm{ZnSO}_{4}$, $\mathrm{FeSO}_{4}, \mathrm{CaCl}_{2}$ ) developed in the Laboratório de Fisiologia Bacteriana, Departamento de Bacteriologia, IOC-Fiocruz (Cavados et al. 1998).

Growth started with a pre-inoculum to reduce the duration of the lag phase of bacterial growth. After inoculation in $125 \mathrm{ml}$ Erlenmeyer flasks containing $50 \mathrm{ml}$ of the medium, the flasks were incubated in a New Brunswick Scientific agitator series $25 \mathrm{D}$, at $175 \mathrm{opm}$ and $30^{\circ} \mathrm{C}$ for $6 \mathrm{~h}$. Subsequently, $3 \mathrm{ml}$ were transferred to $500 \mathrm{ml}$ Erlenmeyer flasks containing $150 \mathrm{ml}$ of the soy flour and inorganic salts medium and incubated as previously described for a further $72 \mathrm{~h}$ period.

Once sporulation had reached $95 \%$ of free spores and crystals, each culture was centrifuged $\left(6000 \mathrm{~g}, 10^{\circ} \mathrm{C}\right)$, the supernatant removed and the remaining material was kept in an amber container with the $\mathrm{pH}$ adjusted to 5.0 with propionic acid and then formulated (Rabinovitch et al. 1998).

Determination of the dry weight - Samples of $0.5 \mathrm{mg}$ biomass were weighed. For each sample three replications were done which were kept for $24 \mathrm{~h}$ in a vacuum oven at $70^{\circ} \mathrm{C}$ under negative pressure of $62 \mathrm{~mm} \mathrm{Hg}$. Dried biomasses were transferred to a desiccator and placed under a vacuum for $1 \mathrm{~h}$ until they reached room temperature. Dried material was then weighed up to the fourth decimal place, and then, the mean weight of the dry biomass and its moisture content were determined.

Counting viable cells - A sample corresponding to 25 $\mathrm{mg}$ (dry weight) of the biomass was transferred to a $50 \mathrm{ml}$ volumetric flask; distilled sterile water was added to a final volume of $50 \mathrm{ml}$ and the solution was homogenized for $5 \mathrm{~min}$. This standard suspension thus contained 0.5 $\mathrm{mg} / \mathrm{ml}$. For the quantification of viable spores, $5 \mathrm{ml}$ of this solution was subjected for $12 \mathrm{~min}$ to $80^{\circ} \mathrm{C}$ in a water bath. Immediately after cooling to room temperature, serial dilutions down to $1: 10^{5}$ were prepared in sterilized tubes, 0.1 $\mathrm{ml}$ was drawn from the last three dilutions $\left(1: 10^{3}, 1: 10^{4}\right.$, $1: 10^{5}$ ) and spread onto the surface of nutrient agar poured into Petri dishes. Three dishes were used for each dilution and incubation was for $24 \mathrm{~h}$ at $33^{\circ} \mathrm{C}$. The colonies were counted, the average determined and the number of spores/mg calculated.

Bioassays against Ae. aegypti - The World Health Organization assay protocol (WHO/8CV/IC-GE/8713) was used to evaluate the $50 \%$ lethal concentration $\left(\mathrm{LC}_{50}\right)$ against $\mathrm{L}_{3}-\mathrm{L}_{4}$ of Ae. ageypti (strain Rockfeller). For each bioassay was used 600 larvae and the mean $\mathrm{LC}_{50}$ was based at least on three different assays performed at room temperature. Assessment of the biological activity was determined through Log-Probit analysis (Finney 1952).
Bioassays against S. pertinax - The formulations of strains LFB-FIOCRUZ 584 and 1035 were sent to the Laboratório de Simulídeos, Superintendência de Controle de Endemias, São Paulo. Assays against black fly larvae (each one with 600 larvae) were carried out in artificial breeding-sites of S. pertinax in the field according to the methodology described by Araújo-Coutinho (1995) and the mean $\mathrm{LC}_{50}$ was calculated based on at least three different bioassays. Assessment of the biological activity was determined through Log-Probit analysis (Finney 1952).

\section{RESULTS AND DISCUSSION}

The use of biological control as one of the strategies to control insect populations has increased over the past few years with the use of $B$. thuringiensis serovar israelensis based insecticides in many vector control programs around the world (Araújo-Coutinho 1995, Hougard 1997, Gray et al. 1999).

From 1995 to 1998 a program to isolate new bacteria was conducted by the Laboratório de Fisiologia Bacteriana in order to find entomopathogenic Bacillus naturally occurring in Simulium larvae and adults. The larvae were collected from different breeding-sites in the states of Rio de Janeiro and São Paulo. Some of the breedingsites were treated with $B$. thuringiensis serovar israelensis products, and others were used as control areas. Eighteen strains of $B$. thuringiensis and one B. sphaericus were isolated (Cavados et al. 2001). One B. thuringiensis strain (LFB-FIOCRUZ 1035), an autoagglutinanting strain demonstrated high activity against Ae. aegypti larvae in preliminary tests. It is important to emphasize that "autoagglutinanting" strains have eluded H-classification because suspensions of these strains in sterile $\mathrm{NaCl} 0.85 \%$ agglutinated spontaneously in the absence of specific antiserum (Cavados et al. 2001)

The biological activity of the formulated biomass from the autoagglutinating strain (LFB-FIOCRUZ 1035) was then determined and compared with that of the reference, $B$. thuringiensis israelensis IPS 82. The results showed that this new strain was more toxic against Ae. aegypti and also against $S$. pertinax than the classic strain used as the active ingredient in commercial insecticides. In the assays of biological activity against Ae. aegypti larvae using the strain LFB 1035, the $\mathrm{LC}_{50}$ was $0.0014 \mathrm{mg} / \mathrm{l}$ (IC $95 \%=0.0012-0.0017)$ and for the standard the $\mathrm{LC}_{50}$ was $0.0039 \mathrm{mg} / \mathrm{l}(\mathrm{IC} 95 \%=0.0029-0.0053)$. For S. pertinax larvae, the bioassays were performed in simulated field trials and the $\mathrm{LC}_{50}$ for the strain 1035 was $0.135 \mathrm{mg} / \mathrm{l}$ (IC $95 \%=$ 0.049-0.403) and for the strain LFB 584 the $\mathrm{LC}_{50}$ was 3.358 $\mathrm{mg} / \mathrm{l}(\mathrm{IC} 95 \%=2.841-3.970)$.

Strain 1035 was 2.8 times more effective against $A e$. aegypti than the IPS-82 strain, and it was 25 times more effective against $S$. pertinax than the standard strain used routinely in programs to control black flies in the Southeast region of Brazil (Araújo-Coutinho 1995).

Finally, we noted that the number of colony-forming units of the LFB 1035 sample was smaller by a factor of ten than that of IPS-82 strain, thus showing that even with a lower concentration of toxic proteins per milligram 
of material applied, it was still more toxic. The results of the counting of the number of viable cells/colony formation units per milligram (ufc/mg) showed that strain LFB 1035 had $6.9 \times 10^{6}$ cells/mg of biomass, while strain LFB 584 had $2.45 \times 10^{7}$ cells $/ \mathrm{mg}$.

The results obtained here with this autoagglutinating B. thuringiensis strain are in accordance with those of Ragni et al. (1996) and Cavados et al. (1998), which showed that autoagglutinating strains of $B$. thuringiensis can be more effective against certain insects than the strain currently used for biological control of Dipteran vectors.

Additional studies are needed to explain why this strain is more toxic to its natural host, $S$. pertinax than to $A e$. aegypti, since the results of protein profile analysis (Cavados et al. 2001) showed that this sample has the same proteins as present in the parasporal body of $B$. thuringiensis serovar israelensis IPS 82 which does not produce exotoxins. But whatever the underlying cause, it appears to be very promising for future use as a biological control agent.

\section{ACKNOWLEDGEMENTS}

To Andréa Barros Pinto Viviani, from Superintendência de Controle de Endemias, SP, for performing the bioassays against Simulium pertinax. To Dr Anthony J Shelley, from the Natural History Museum of London, UK; Dr James J Becnel, from US Department of Agriculture, Gainesville, FL, and Dr Lucy Seldin, from UFRJ for revising this manuscript.

\section{REFERENCES}

Araújo-Coutinho CJPC 1995. Biological control programme against simuliids in the state of São Paulo, Brazil. Mem Inst Oswaldo Cruz 90: 131-134.

Asimeng EJ, Mutinga MJ 1992. Isolation of mosquito-toxic bacteria from mosquito breeding sites in Kenya. J Am Mosq Control Assoc 8: 86-88.

Cavados CFG, Chaves JQ, Queiroz MMC, Serra-Freire NM, Rabinovitch L 1998. An assessment of the biological activity of Bacillus thuringiensis LFB-FIOCRUZ 907 in Chrysomya megacephala (Diptera: Calliphoridae). Israel J Entomol 32: 117-123.

Cavados CFG, Fonseca RN, Chaves JQ, Rabinovitch L, AraújoCoutinho CJPC 2001. Identification of entomopathogenic Bacillus isolated from Simulium (Diptera: Simuliidae) larvae and adults. Mem Inst Oswaldo Cruz 96: 1017-1021.

Chilcott CN, Wigley PJ 1993. Isolation and toxicity of Bacillus thuringiensis from soil and insects habitats in New Zealand. J Invert Pathol 61: 244-247.
Finney DJ 1952 . Probit Analysis, 2nd ed, University Press, London, Cambridge.

Gray EW, Adler PH, Coscaron-Arias C, Coscaron S, Noblet R 1999. Development of the first black fly (Diptera: Simuliidae) management program in Argentina and comparison with other programs. J Am Mosq Control Assoc 15: 400-406.

Hougard JM, Yaméogo L, Sékètéli A, Boatin B, Dadzie KY 1997. Twenty-two years of blackfly control in the Onchocerciasis control programme in West Africa. Parasitol Today 13: 425-431.

Knowles BH 1994. Mechanism of action of Bacillus thuringiensis insecticidal $\delta$-endotoxin. Adv Insect Physiol 24: 275-308.

Rabinovitch L, Jesus FF, Cavados CFG, Zahner V, Momen H, Silva MHL, Cosmao-Dumanoir V, Frachon E, Lecadet MM 1995. Bacillus thuringiensis subsp. oswaldocruzi and Bacillus thuringiensis subsp. brasiliensis, two novel Brazilian strains which determine new serotype H38 and H39, respectively. Mem Inst Oswaldo Cruz 90: 41-42.

Rabinovitch L, Silva CMB, Alves RSA, Consoli RGAB, Santos BS, Lamounier MA 1998. Produção de bioinsecticidas à base de Bacillus thuringiensis sorovar israelensis e Bacillus sphaericus. Anais do $4^{\mathrm{O}}$ Simpósio Controle Biológico, Rio de Janeiro, p. 479-483.

Ragni A, Thiéry I, Delécluse A 1996. Characterization of six highly mosquitocidal Bacillus thuringiensis strains that do not belong to H-14 serotype. Curr Microbiol 32: 48-54.

Schenpf E, Crickmore N, Van Rie J, Lereclus D, Baum J, Feitelson J, Zeigler DR, Dean DH 1998. Bacillus thuringiensis and its pesticidal crystal proteins. Microbiol Mol Biol Rev 62: 775-806.

Siegel JP 2001. The mammalian safety of Bacillus thuringiensisbased insecticides. J Invert Pathol 77: 13-21.

Van Rie J, Jansens S, Hofte H, Degheele D, Van Mellaert H 1990. Receptors on the brush border membrane of the insect midgut as determinants of the specificity of Bacillus thuringiensis delta-endotoxins. Appl Environ Microbiol 56: 1378-1385.

Weiser J 1984. A mosquito virulent Bacillus sphaericus in Simulium damnosum from Northern Nigeria. Zbl Mikrobiol 139: 57-60.

WHO-World Health Organization 1987. Report of an informal consultation on the detection, isolation, identification and ecology of biocontrol agent diseases vectors. TDR/BCV/ IC-GE/ 87-3, Annex II, p 12, Geneva. 